\title{
KEMAMPUAN MENULIS TEKS NARATIF STUDI KASUS KORELASI KECERDASAN EMOSIONAL DAN BERPIKIR KREATIF DENGAN KEMAMPUAN MENULIS NARASI
}

\author{
Tangson R. Pangaribuan ${ }^{1}$, Sahat Siagian ${ }^{2}$, R. Mursid $^{3}$ \\ ${ }^{1}$ Jurusan Bahasa dan Sastra Indonesia, Universitas Negeri Medan, Medan \\ ${ }^{2,3}$ Program Pascasarjana, Universitas Negeri Medan, Medan \\ Itangsonrpangaribuan@gmail.com; ${ }^{2}$ sahat.sgn61@gmail.com; ${ }^{3}$ mursid.tp@gmail.com
}

\begin{abstract}
Abstrak: Penelitian ini bertujuan untuk menggambarkan hubungan: (1) kecerdasan emosional dan kemampuan menulis narasi; (2) Berpikir kreatif dengan kemampuan menulis narasi; serta (3) kecerdasan emosional dan berpikir kreatif secara bersama-sama dengan dengan kemampuan menulis narasi. Penelitian ini dilaksanakan pada Jurusan Bahasa dan Sastra Indonesia Prodi Pendidikan Bahasa dan Sastra Indonesia FBS Universitas Negeri Medan. Metode yang digunakan dalam penelitian ini adalah metode survai dengan teknik korelasi. Populasi penelitian adalah seluruh mahasiswa semester V Prodi Pendidikan Bahasa dan Sastra Indonesia FBS Universitas Negeri Medan. Sampel yang digunakan sebanyak 40 mahasiswa yang diambil dengan teknik random sampling. Hasil analisis data penelitian menunjukkan bahwa (1) terdapat hubungan positif antara kecerdasan emosional (XI) dengan kemampuan menulis narasi (Y) dengan kadar hubunga (ry $)$ sebesar 0.747 dan dengan bentuk persamaan regresi $\hat{Y}=35.55+0.74 X 1$; (2) terdapat hubungan positif antara berpikir kreatif dengan kemampuan menulis narasi $(Y)$ dengan ry $y_{2}=0.707$ dan persamaan regresi $\hat{Y}$ $=57.69+0.90 X 2$. dan (3) terdapat hubungan positif antara kecerdasan emosional $\left(X_{1}\right)$ dan berpikir kreatif $\left(X_{2}\right)$ secara bersama-sama $Y$ dengan $R y_{12}=0.856$ dan persamaan regresi sebesar $\hat{Y}=15.55+0.54 X_{1}+$ $0.60 X_{2}$.
\end{abstract}

Kata Kunci: kemampuan menulis teks naratif, kecerdasan emosional, berfikir kreatif, kemampuan menulis narasi,

Abstract: This study aims to describe the relationship: (1) emotional intelligence and the ability to write narratives; (2) Creative thinking with the ability to write narratives; and (3) emotional intelligence and creative thinking together with the ability to write narratives. This research was conducted at the Indonesian Language and Literature Department of Indonesian Language and Literature Education Study Program FBS Medan State University. The method used in this study is a survey method with correlation techniques. The study population was all V semester students of Indonesian Language and Literature Education Study Program FBS Medan State University. The sample used was 40 students taken by random sampling technique. The results of the research data analysis show that (1) there is a positive relationship between emotional intelligence (X1) and the ability to write narratives $(Y)$ with correlation levels (ryl) of 0.747 and the regression equation $\hat{Y}=$ $35.55+0.74 X 1 ;(2)$ there is a positive relationship between creative thinking and the ability to write narratives (Y) with ry $2=0.707$ and the regression equation $\hat{Y}=57.69+0.90 X 2$. and (3) there is a positive relationship between emotional intelligence (X1) and creative thinking (X2) together $Y$ with Ry12 $=0.856$ and the regression equation is $\hat{Y}=15.55+0.54 X 1+0.60 X 2$.

Keywords: the ability to write narrative texts, emotional intelligence, creative thinking, the ability to write narratives

\section{PENDAHULUAN}

Menulis bukanlah semata menuliskan satu atau sejumlah kalimat tanpa aturan yang jelas. Menulis akan menghasilkan serangkaian kalimat yang tersusun secara beraturan dan saling berkaitan, sehingga terbentuklah rangkaian kalimat yang terstruktur secara bermakna dan logis dalam sebuah teks. Ini semua bukanlah aktivitas yang mudah dan spontan melainkan sebuah keterampilan tersendiri dan harus dipelajari.

Pada pihak lain, pekerjaan menulis juga dimungkinkan apabila penulis berada dalam kondisi psikologis atau mood yang baik atau 
berada pada suatu keharusan untuk mengekspresikan sesuatu. Hal ini membenarkan bahwa menulis membutuhkan beberapa kesadaran mental di mana kita memikirkan kalimat-kalimat dan mempertimbangkan berbagai cara untuk menggabungkan dan menyusun kalimat-kalimat tersebut ke dalam struktur yang logis dan harmonis. Kondisi tersebut akan sulit apabila mood tidak dalam kondisi bagus atau kita tidak dapat mengatur emosi dan perasaan kita. Menulis juga dipengaruhi oleh kreativitas seperti kelancaran dalam pengungkapan kata, keluwesan dan keorisinilan mengungkapkan ide dan gagasan serta kemampuan menyelesaikan suatu masalah dengan cara yang sangat menarik atau tidak biasa dalam tulisannya.

Menjadi seorang penulis adalah suatu proses yang kompleks dan perlu latihan secara terus menerus sehingga pembelajaran menulis menjadi suatu yang sangat penting. Hal ini disebabkan karena aktivitas menulis tidak hanya menggunakan salah satu keterampilan otak (kiri atau kanan) tetapi juga menyangkut aktivitas seluruh otak baik itu menggunakan otak bagian kiri maupun otak bagian kanan. Dengan kata lain seorang penulis dalam membuat tulisannya dipengaruhi oleh dua macam faktor yaitu faktor emosi yang mencakup imajinasi, gairah, emosi, spontanitas, semangat, dan sebagainya dan faktor logika seperti outline, tata bahasa, perencanaan, tanda baca, penelitian, dan sebagainya ( DePorter and Hernacky, 2000: 179).

Dari uraian di atas lebih lanjut dipahami bahwa menulis itu merupakan proses yang kompleks dan perlu latihan secara terusmenerus. Dalam proses demikian, pembelajaran menulis menjadi sesuatu yang sangat penting. Hal ini disebabkan karena aktivitas menulis tidak hanya menggunakan salah satu keterampilan otak (kiri atau kanan) tetapi juga menyangkut aktivitas seluruh otak baik itu menggunakan otak bagian kiri maupun otak bagian kanan. Dengan kata lain seorang penulis dalam membuat tulisannya dipengaruhi oleh dua macam faktor yaitu faktor emosi yang mencakup imajinasi, gairah, emosi, spontanitas, semangat, dan sebagainya dan faktor logika seperti outline, tata bahasa, perencanaan, tanda baca, penelitian, dan sebagainya ( De Porter and Hernacky, 2000: 179).

Kecerdasan emosional (EQ) dan kemampuan berpikir kreatif keduanya sangat penting dalam proses pendidikan sama kedudukannya dengan kecerdasan intelektual (IQ). Akan tetapi, baik kecerdasan emosi maupun kemampuan berpikir kreatif tidak memiliki tempat atau porsi yang sama dengan kecerdasan intelektual dalam proses belajar mengajar di sekolah. Dalam pendidikan formal, kreativitas dan kecerdasan emosi seharusnya merupakan bagian terpenting sebagai perkiraan keberhasilan pendidikan dan mampu menggali kreativitas peserta didiknya.

Demikian pula proses belajar bahasa khususnya belajar menulis, sistem penilaian yang dikembangkan menekankan pada porsi tata bahasa, ejaan, tanda baca, atau outline yang semuanya cenderung mengarah pada berpikir konvergen yaitu mengandalkan otak bagian kiri. DePorter (2000: 179) mengatakan bahwa tulisan yang baik memanfaatkan kedua belahan otak baik bagian kiri maupun bagian kanan.

Dari pengalaman selama mengajar bahasa khususnya menulis baik ditingkat SMA maupun Perguruan Tinggi, diperoleh gambaran bahwa rata-rata pembelajar mengalami kesulitan atau bahkan tidak mampu mengungkapkan ide dan imajinasi mereka ke dalam bentuk tulisan narasi yang baik. Kelemahan ini menjadi fenomena keseharian yang menyebabkan kemampuan menulis narasi mereka masih rendah.

Rendahnya kemampuan menulis narasi sebagaimana disebutkan di atas sebenarnya dapat disebabkan oleh berbagai faktor baik itu yang bersifat internal maupun eksternal. Faktorfaktor seperti kecerdasan emosional dan kemampuan berpikir kreatif merupakan dua variabel yang patut diperhitungkan. Pertanyaannya kemudian adalah, apakah ada hubungan yang berarti antara kecerdasan emosional dan berpikir kreatif dengan kemampuan menulis narasi? Hal ini merupakan masalah urgen yang membutuhkan penelitian yang luas dan mendalam.

\section{Hakikat Kemampuan Menulis Narasi}

Kemampuan merupakan usaha maksimum seseorang untuk melakukan suatu kegiatan (Wells, 1981: 276). Chomsky (1955: 65) menamakan kemampuan dengan istilah competence, yaitu perangkat aturan-aturan bahasa yang jika dikuasai menyanggupkan seseorang membuat dan memahami kalimatkalimat yang tidak terbatas jumlahnya. Lebih lanjut ia memunculkan istilah linguistics competence atau kemampuan bahasa yang 
pengertiannya identik dengan kemampuan seseorang dalam menguasai struktur bahasa.

Wells, (1981: 276) mengungkapkan bahwa kemampuan merupakan suatu usaha maksimum seseorang untuk melakukan suatu kegiatan. Dengan demikian usaha untuk mencapai hasil yang tinggi didorong oleh motivasi yang tinggi pula. Dengan kata lain, motivasi akan menambah kemampuan seseorang untuk mencapai kerja yang maksimum. Dalam hal ini, kemampuan adalah kesanggupan seseorang untuk mencapai hasil yang maksimum dengan motivasi yang tinggi.

Istilah menulis dalam Bahasa Indonesia tidak memiliki perbedaan dengan mengarang. Menulis (mengarang) menurut The Liang Gie adalah keseluruhan rangkaian kegiatan seseorang mengungkapkan gagasan dan menyampaikannya melalui bahasa tulis kepada pembaca untuk dipahami (The Liang Gie, 1995: 17) Agar pembaca mudah memahami apa yang ditulis oleh seorang penulis, maka penulis haruslah menggunakan aturan-aturan yang telah disepakati seperti tanda baca, huruf besar, koma, tanda seru dan sebagainya. Hal ini pernah dilontarkan secara implisit oleh Sauli Takala yang dikutip Akhmadi (1990: 7) yang mengatakan bahwa mengarang adalah suatu proses menyusun, mencatat dan mengkomunikasikan makna dalam tataran ganda, bersifat interaktif dan diarahkan untuk mencapai tujuan tertentu dengan menggunakan suatu sistem tanda konvensional yang dapat dilihat (dibaca). White dikutip Robinson (1998: 5) menyatakan bahwa menulis adalah sebuah cara (alat) penguatan bahasa yang berasal dari bahasa lisan di mana penekanannya pada pembetulan, kepatuhan dan menyalin (meniru) aturan-aturan baik itu aturan bahasa maupun aturan teknis (Robinson, 1995: 5)

Menulis dipandang sebagai alat komunikasi secara tertulis antara penulis dan pembaca. Agar tulisannya dapat dibaca dan dipahami oleh pembaca maka diperlukan suatu konvensi tertentu seperti konvensi suatu kalimat, paragraf, dan teks yang baik dan bagaimana ide-ide dari penulis disampaikan oleh penulis sesuai dengan tujuan penulisan yang dapat mengena terhadap pembacanya. Hal ini disampaikan oleh Collins dan Gentner dikutip Forrester (1996: 72) yang mendefenisikan menulis sebagai suatu proses mengembangkan dan mengedit teks dalam berbagai macam batasan yaitu : batasan struktural (structural constraint), batasan isi (content constraint), dan batasan tujuan (purpose constraint). (1) Batasan struktural didefenisikan sebagai bentuk konvensi kalimat, paragraf, dan teks yang baik, (2) batasan isi berasal dari ide-ide yang harus didefenisikan satu sama lain, dan (3) batasan tujuan ditekankan pada tujuan dan gaya penulis kepada pembacanya. Ketiga komponen tersebut yaitu isi, struktural atau bisa dikatakan strategi dan tujuan yang cenderung pada style penulis merupakan satu kesatuan yang membentuk suatu karangan yang siap disajikan.

Narasi berasal dari kata "Narrate" yang artinya bercerita, narasi adalah jenis paparan yang biasa digunakan oleh para penulis untuk menceritakan tentang rangkaian kejadian atau peristiwa-peristiwa yang berkembang melalui waktu (Hughey, 1983: 140). Seperti yang dikatakan Gillespie dkk. (1982: 29), "Narration is storytelling, which answer the questions "What happened?" and deals heavily in time and verbs". Hal ini sejalan dengan apa yang dinyatakan Kirszner and Mandell (1983: 33) yang menyatakan bahwa sebuah narasi adalah menceritakan suatu cerita tentang suatu rangkaian kejadian. Akan tetapi narasi tidak hanya mengupas kejadian atau peristiwa saja, namun ada unsur lain dari selain waktu yaitu adanya perbuatan atau tindakan dari tokoh unsur perbuatan atau tindakan, dan waktu merupakan unsur penting sebuah narasi. Sebuah narasi terjadi tidak lain tindak-tanduk yang dilakukan oleh orang-orang atau tokoh-tokoh dalam suatu rangkaian waktu (Keraf, 2001: 136).

Sebuah narasi merupakan suatu peristiwa atau kejadian yang dilakukan tokoh dalam suatu rangkaian waktu tertentu. Dalam sebuah narasi, peristiwa yang terjadi tidaklah datar, namun terdapat klimaks atau bersifat dinamis dan memiliki alur atau plot yang didasarkan pada kesinambungan peristiwaperistiwa dalam hubungan sebab-akibat. Seperti apa yang dinyatakan Gillespie, sebuah cerita biasanya memiliki (1) Plot (alur); (2) Konflik; dan (3) Tema. Plot dapat didefenisikan sebagai sebuah rangkaian yang berhubungan dengan kejadian. Alur dalam suatu cerita dapat digambarkan sebagai suatu keadaan yang melewati lima tingkatan dasar: (1) Eksposisi (menerangkan tentang pentingnya informasi, bisanya mengenai kejadian yang berlangsung), (2) Komplikasi atau meningkatnya tindakan sebagai hasil dari konflik; (3) Krisis atau Klimaks atau perubahan pandangan yang 
diikuti oleh; (4) Turunnya tindakan; dan (5) pemecahan atau kesimpulan akhir (penyelesaian permasalahan). Tema sebagai pengontrol ide dari cerita (Gillespie, 1982: 139-140)

Begitu pula dengan Keraf (2001: 145) yang menyatkan bahwa : ditinjau dari segi bentuknya, narasi memiliki komponenkomponen tertentu yang membentuknya yaitu perbuatan, penokohan, latar dan sudut pandang. Tetapi dapat juga dianalisis berdasarkan alur (plot) nya.

Bentuk sebuah narasi secara umum terdiri dari tiga bagian, yaitu ; bagian pendahuluan, perkembangan, dan penutup seperti apa yang dinyatakan Aristoteles bahwa sebuah tragedi dibagi dalam tiga bagian utama yaitu bagian pendahuluan, bagian perkembangan, dan bagian penyelesaian. Bagian pendahuluan (paragraf) bertujuan untuk mendapatkan perhatian dari pembacanya atau merupakan ajakan dari maksud sebuah tulisan (Mc. Crimmons, 1984: 159). Bagian ini menyangkut situasi dasar, memungkinkan pembaca memahami adegan-adegan selanjutnya (Keraf 2001: 152). Jadi bagian pendahuluan sangat penting dalam menentukan sebuah narasi itu menarik atau tidak karena merupakan kesan awal pada pembaca. Apabila tulisan itu menarik, maka pembaca akan melanjutkan membacanya. Begitu pula sebaliknya apabila tulisan awal itu tidak menarik pembacanya, maka pembaca juga tidak akan meneruskan membacanya.

Hairston (1986: 228) mengemukakan ada tiga hal yang harus diperhatikan dalam menarik pembacanya yaitu: (1) Menangkap perhatian pembaca; (2) Membuat sebuah janji atau komitmen yang menyatakan pada pembaca harapan-harapan setelah membaca tulisan tersebut; (3) Menunjukkan pada pembaca mengapa dia harus meneruskan membaca.

Bagian perkembangan mencakup adegan-adegan yang berusaha meningkatkan ketegangan atau mengawetkan komplikasi yang berkembang dari situasi asli atau bisa dikatakan terjadinya konflik yang terbuka maupun yang tertutup, bagian pertikaian-pertikaian antar tokoh yang dikisahkan berangsur-angsur memuncak melalui perumitan masalah (Keraf, 2001: 153). Konflik hanya dapat dipahami dan dimengerti dengan baik kalau situasi awal dalam bagian pendahuluan sudah disajikan secara jelas. Jadi bagian perkembangan merupakan sebab-akibat dari tindakan dan peristiwa pada waktu lampau.
Bagian penutup / penyelesaian atau bisa juga disebut paragraf penutup harus menyajikan pembacanya menyelesaikan cerita, memberikan sebuah perasaan yang menyatakan bahwa penulis telah menjelaskan pembicaraannya pada apa yang telah dikatakan (Hairston,1986: 228). Lebih tepat dikatakan bahwa bagian ini merupakan akhir dari tindakan atau peristiwa pada suatu situasi yang tercipta sejak semula dan menemukan pemecahannya atau bagian penutup ini merupakan titik di mana para pembaca sepenuhnya merasa bahwa struktur dan makna sebenarnya merupakan unsur dari persoalan yang sama : keduanya adalah persoalan itu sendiri (Keraf, 2001: 154-155).

Namun bagian penutup ini bukan berarti akhir dari persoalan karena bisa saja suatu penyelesaian justru awal dari persoalan seperti dikatakan Keraf bahwa penyelesaian itu tidak ada. Yang ada adalah diskusi yang menjadi pangkal bagi persoalan baru (Keraf, 2001: 154-155). Jadi, bagian penyelesaian atau akhir dari suatu tindakan di sini dalam pengertian alur.

Dapatlah disimpulkan di sini bahwa narasi adalah suatu bentuk cerita yang mencakup rangkaian tindakan tokoh dalam suatu rangkaian waktu yang memiliki suatu alur. Dalam narasi haruslah terdapat tiga bagian yaitu bagian pendahuluan, bagian perkembangan dan bagian penutup. Alur dalam narasi haruslah terdapat klimaks-klimaks yang berakhir pada suatu penyelesaian.

Dari uraian di atas dapatlah ditarik kesimpulan bahwa Kemampuan menulis narasi adalah kecakapan/kesanggupan untuk melakukan suatu bentuk komunikasi secara maksimal dalam aktivitas mengungkapkan ide atau gagasan dalam bentuk cerita yang mencakup rangkaian tindakan tokoh dalam suatu rangkaian waktu yang memiliki alur kedalam bahasa tulis yang baik dan benar, dan sesuai dengan aturan-aturan penulisan yang berlaku seperti (ejaan, titik, tanda koma, dan sebagainya) agar mudah dipahami membacanya.

\section{Hakikat Kecerdasan Emosional}

Kecerdasan atau Intelligence banyak memiliki pengertian. Feldman (1987: 213) mengatakan setidaknya ada 3 pengertian kecerdasan yaitu pertama, kemampuan seorang dalam memecahkan masalah, kedua, kemampuan verbal berpikir yang ditunjukkan pada kecerdasan. Ketiga, intellegensi 
diasumsikan sebagai kemampuan sosial yaitu kemampuan yang menunjukkan keterkaitan pada yang lain dan mampu berinterasi dengan mereka secara efektif. Sejalan dengan hal tersebut, Adler (2001: 15) menyatakan bahwa inteligensi (kecerdasan) adalah suatu ukuran yang digunakan agar kita dapat memecahkan masalah, mendapatkan kesenangan dan bertahan hidup. Singkatnya tingkat di mana kita mencapai tujuan kita.

Akan tetapi defenisi-defenisi tersebut masih bersifat umum. Defenisi kecerdasan yang dikemukakan para ahli psikologi lebih terfokus. Menurut mereka kecerdasan adalah kemampuan dalam memahami dunia, berpikir secara rasional dan mampu memanfaatkan sumber daya secara efektif ketika menghadapi tantangan Feldman (1987: 213). Stones (1971: 283) mengatakan kecerdasan sebagai kemampuan bawaan, kemampuan umum, dan kemampuan kognitif.

Dapatlah disimpulkan bahwa kecerdasan adalah suatu kemampuan berpikir, kemampuan bawaan dan kemampuan umum dalam menghadapi suatu tantangan atau masalah secara efektif.

Secara Psikologis emosi adalah perasaan yang secara umum memiliki unsur psikologis dan unsur kognitif yang mempengaruhi tingkah laku Feldman (1987: 262). Contoh : perasaan senang, pertama-tama kita merasa bahagia ada perubahan seperti hati berdebar-debar keras yang berlanjut pada tindakan yaitu meloncat kegirangan.

Goleman (1995: 6-7) menyatakan bahwa akar kata dari emosi adalah "motere" dari bahasa latin yang berarti bergerak ditambah prefiks "e" yang mengandung arti "bergerak menjauh" yang mengisyaratkan bahwa kecenderungan bertindak merupakan hal mutlak dalam setiap emosi. Lebih lanjut dia mengatakan bahwa emosi menunjuk pada sebuah perasaan dan pikiran-pikiran tersendiri. Pernyataan-pernyataan psikologis dan biologi dan sebuah kecenderungan untuk bertindak

Dengan demikian emosi mengandung kekuatan yang luar biasa bagi manusia karena emosi menyangkut perasaan, pikiran dan tindakan seseorang dalam menanggapi keadaan atau kondisi tertentu. Begitu pentingnya emosi, membuat Aristoteles pernah mengatakan bahwa siapapun bisa marah, marah itu mudah, tetapi marah pada orang tepat, dengan kadar yang sesuai, pada waktu yang tepat demi tujuan yang benar, dan dengan cara yang baik, bukanlah hal yang mudah (Goleman, 1995: 6-7).

Kecerdasan emosional berbeda dengan kecerdasan intelektual Bar-On. Melihat keterampilan kecerdasan emosional sebagai kemampuan yang bersifat non-kognitif. Beliau mendefenisikan kecerdasan emosi sebagai berikut : "emotional intelligence is an array of non cognitive capabilities, competencies, and skills that influence one's ability to succed in coping with environmental demands and pressure" (Anon, 2003: 3).

Kecerdasan emosional menjadi populer berkat buku dari Daniel Goleman pada tahun 1995 "Emotional intelligence: Why it can More Than IQ." Lebih lanjut Goleman mengatakan bahwa kecerdasan emosional adalah kemampuan untuk mengenali perasaan diri kita dan perasaan orang lain, memotivasi diri sendiri, dan mengatur emosi dengan baik dalam hubungan antara kita dan orang lain. Goleman, 1995: 4). Kecerdasan emosional bukan merupakan lawan dari kecerdasan intelektual yang biasa dikenal dengan IQ. Namun keduanya berinteraksi secara dinamis. Pada kenyataanya perlu diakhiri bahwa kecerdasan emosional memiliki peran yang sangat penting untuk mencapai kesuksesan di sekolah, tempat kerja dan dalam berkomunikasi dengan masyarakat. Goleman dalam bukunya menyatakan bahwa IQ penyumbang paling banyak $20 \%$ bagi sukses dalam hidup sedangkan $80 \%$ ditentukan faktor lain-lain.

Kecerdasan emosional menurut Goleman merujuk pada kemampuan mengelola emosi dengan baik pada diri sendiri maupun dalam hubungannya dengan orang lain (Goleman, 1995: 34). Selanjutnya (Goleman, 1995: 43) mengungkapkan lima wilayah kecerdasan emosional yang dapat menjadi pedoman bagi individu untuk mencapai kesuksesan dalam kehidupan sehari-hari, yaitu: menganalisis emosi diri (knowing one's emotional); mengelola emosi (managing emotions); memotivasi diri (motivating the self); menganalisis emosi orang lain (recognizing emotions in other); dan membina hubungan dengan orang lain (handling relationship). Kecerdasan emosional berbeda dengan kecerdasan intelektual Bar-On. Melihat keterampilan kecerdasan emosional sebagai kemampuan yang bersifat non-kognitif. Beliau mendefenisikan kecerdasan emosi sebagai berikut : "emotional intelligence is an array of non cognitive capabilities, competencies, and 
skills that influence one's ability to succed in coping with environmental demands and pressure" (Anon, 2003: 3).

\section{Hakikat Berpikir Kreatif}

Berpikir dalam bahasa Inggris disebut "thinking". Berpikir merupakan karakter / sifat khusus bagi manusia karena berpikir membedakan antara manusia dan binatang lainnya. Walaupun penelitian menunjukkan bahwa binatang juga mengalami proses berpikir namun itu hanya mampu pada tahap awal dari proses berpikir (Vinacke, 1971: 1). Bagi faham assosiation berpikir adalah sebuah rangkaian dan hubungan antara stimulus respon (Thomas, 1990: 291). Dalam penggunaan sehari-hari, "berpikir berhubungan pada refleksi (reflection) atau meditasi (meditation), keyakinan, opini, penilaian atau adegan-adegan (Vinacke, 1971: 3). Namun demikian pengertian tersebut sulit dipahami dan proses yang melibatkan sulit diteliti secara langsung.

Kreatif (creativity) didefenisikan sebagai pemikiran yang menghasilkan sesuatu yang baru dan berguna untuk memecahkan masalah (Newmann and Newmann, 1983: 273). Para ahli psikologi yang dikutip oleh Newman mendefenisikan kreatif sebagai gabungan dari respon-respon atau ide-ide dalam menghadapi situasi sekarang untuk memperoleh sesuatu yang baru atau tidak biasa sehingga, seorang yang kreatif adalah seorang yang mampu menghasilkan sesuatu yang baru atau tidak biasa (Thomas, 1990: 271). Kreativitas menurut Csikszentmihalyi (1996: 28) beberapa aktivitas, ide, atau produk yang merubah keberadaan domain (bidang tertentu seperti Matematika, Budaya, kemanusiaan dan sebagainya) atau mentransformasi keberadaan domain ke dalam suatu bentuk yang baru. (Vinacke, 1971: 335) mendefenisikan kreativitas sebagai aktifitas penyesuaian dari dalam diri (intrinsic activities) dan dorongan dari luar (external condition) dengan memiliki sifat-sifat pemecahan masalah dan fantasi.

Sementara itu di Indonesia tes berpikir kreatif yang disusun oleh Munandar (2003: 95) juga mengacu pada model Guilford yang semuanya mengukur dimensi operasi berpikir divergen. Tes bentuk verbal secara operasional dirumuskan sebagai kelancaran, fleksibilitas, dan orisinalitas terdiri dari 6 subtest yaitu permulaan kata, penyusunan kata, membentuk kalimat 3 kata, sifat-sifat yang sama, penggunaan yang tidak biasa, dan apa akibatnya. Dan tes bentuk non verbal (TKV) 4 aspek berpikir kreatif (kelancaran, kelenturan, orisinalitas, dan elaborasi) juga mengukur kreativitas sebagai kemampuan untuk membuat kombinasi antara unsur-unsur yang diberikan.

Masalah penelitian ini dapat dirumuskan sebagai berikut: (1) Apakah terdapat hubungan positif dan signifikan kecerdasan emosional dengan kemampuan menulis narasi?; (2) Apakah terdapat hubungan positif dan signifikan berpikir kreatif dengan kemampuan menulis narasi?; (2) Apakah terdapat hubungan positif dan signifikan kecerdasan emosional dan berpikir kreatif secara bersama-sama dengan kemampuan menulis narasi?

\section{METODE}

Penelitian ini dilaksanakan pada Fakultas Bahasa dan Sastra Indonesia FBS Universitas Negeri Medan (FBS-Unimed). Penelitian ini dapat digolongkan ke dalam penelitian deskriptif korelasional karena melakukan pengukuran terhadap hal-hal yang nyata terhadap pengertian-pengertian yang abstrak (William, 1979: 297). Dalam penelitian ini pengukuran dilakukan untuk memperoleh data kemampuan menulis narasi, kecerdasan emosinal dan berpikir kreatif.

Populasi penelitian ini adalah seluruh mahasiswa FBS Unimed Jurusan Bahasa dan Sastra Indonesia. Populasi target adalah mahasiswa Program Studi Pendidikan Bahasa dan Sastra Indonesia semester V sedangkan populasi terjangkau adalah mahasiswa Program Studi Pendidikan Bahasa dan Sastra Indonesia semester $\mathrm{V}$ yang berjumlah 40 orang. Pengambilan sampel dilakukan dengan teknik random sampling (Sudjana, 1992: 6). Pertama, dilakukan penetapan jumlah sampel yang memenuhi syarat untuk uji statistik dan kedua, untuk dijadikan sampel dapat dilakukan teknik pengambilan secara acak. Berdasarkan pertimbangan tersebut, maka ditetapkan jumlah anggota populasi.

\section{Teknik Pengumpulan Data dan Instrumen Penelitian}

Data penelitian ini adalah skor kemampuan menulis narasi, skor kecerdasan emosional dan skor berpikir kreatif. Pengumpulan data menggunakan tiga macam instrumen yaitu (1) intrumen berupa tes mengarang untuk mengukur kemampuan 
menulis narasi (2) instrumen berupa skala untuk mengukur kecerdasan emosional dan (3) intrumen berupa tes untuk mengukur berpikir kreatif.

Instrumen yang digunakan untuk mengumpulkan data dalam penelitian ini, harus berkualitas. Oleh karena itu, validitas instrumen harus diwujudkan. Dalam hal ini, validitas isi instrumen tes menulis narasi diwujudkan dengan pengembangan instrumen yang sesuai dengan materi kurikulum dan validitas konstruksinya diwujudkan dengan mengkonsultasikannya kepada ahli (minimal 3 orang ahli bahasa). Validitas instrumen kecerdasan emosional diwujudkan dengan mengembangkan instrumen berdasarkan teori yang mendasarinya yaitu teori yang dikembangkan oleh Robert Wood dan Harry Tolley dalam "Test Your Emotional Intelligence: How to Assest and Boost Your EQ" (Wood and Tolley, 2003) dengan perubahan. Validitas isi instrumen tes kemampuan berpikir kreatif diwujudkan dengan menggunakan instrumen tes yang baku dan disesuaikan dengan teori kemampuan berpikir kreatif; validitas kosntruksinya diwujudkan dengan mengkonsultasikannya kepada ahli.

\section{Teknik Analisis Data}

Data penelitian ini dianalisis dengan statistik deskriptif dan infrensial. Pengujian hipotesis dilakukan setelah melalui tahap pengujian persyaratan analisis yaitu normalitas, homogenitas, linieritas dan keberartian regresi

Sebelum dilakukan pengujian persyaratan analisis untuk setiap data variabel, pendeskripsian data lebih dahulu dilakukan. Dalam hal ini dengan statistik deskripsi akan dideskripsikan mengenai rata-rata (mean), nilai tengah (median), frekuensi terbanyak (modus), dan simpangan baku (standar deviasi).. Data ini selanjutnya dideskripsikan dalam bentuk distribusi frekuensi dan histrogram untuk masing-masing variabel penelitian. Pengujian hipotesis dilakukan dengan menggunakan Uji "t" dan Uji "F". Uji "t" dilakukan untuk korelasi dan regresi sederhana maupun korelasi parsial, dan Uji "F" dilakukan untuk korelasi dan regresi jamak. Sebelum pengujian dilakukan, perhitungan koefisien korelasi dilakukan dengan statistik Korelasi Product Moment sementara bentuk regresi dihitung dengan Analisis Regresi baik sederhana maupun jamak. Penggunaan statistik ini setelah lebih dahulu memenuhi persyaratan analisis yaitu normalitas, homogenitas, linieritas dan keberartian regresi. Uji Independensi dilakukan terutama untuk mengukur apakah variabel X1 dengan X2 independen atau tidak. Untuk hal ini akan diuji hipotesis nol bahwa $\beta=0$ melawan hipotesis tandingan $\beta \neq 0$. Dalam pengujian independensi akan digunakan ststistik "t" dengan formula $t=\frac{b}{s_{b}} \quad$ (Sudjana, 2003:31). Untuk kepraktisan, sebagian perhitungan dilakukan Komputasi perhitungan dengan Program SPSS .

Untuk keperluan pengujian, dirumuskan hipotesis statistik penelitian sebagai berikut.

1. Hipotesis Pertama

Ho $\quad: \rho_{\mathrm{y}} 1=0$

Keterangan :

$\rho_{\mathrm{y}} 1=$ Koorfisien korelasi kecerdasan emosional dengan kemampuan menulis narasi

2. Hipotesis Kedua

Ho $\quad: \rho_{\mathrm{y} 2}=0$

H1 : $\rho_{\mathrm{y}}{ }^{2}>0$

Keterangan

$\rho_{\mathrm{y}} 2=$ Koefisien korelasi berpikir kreatif dengan kemampuan menulis narasi.

3. Hipotesis ketiga

Ho $: \rho_{\mathrm{y}}{ }^{12}=0$

H1 $: \rho_{\mathrm{y}}{ }^{12}>0$

Keterangan

$\rho_{\mathrm{y}}{ }^{12}=$ Koefisien korelasi jamak antara kecerdasan emosional dan berpikir kreatif dengan kemampuan menulis narasi.

\section{HASIL PENELITIAN}

Penelitian ini mengajukan tiga hipotesis penelitian yang perlu diuji secara empiris. Semua hipotesis adalah dugaan tentang hubungan antara kecerdasan emosional dan berpikir kreatif baik secara sendiri-sendiri maupun bersama-sama dengan kemampuan menulis narasi.

\section{Hubungan Kecerdasan Emosional dan Kemampuan Menulis Narasi}

Hipotesis pertama yang diajukan dalam penelitian ini menyatakan terdapat 
hubungan positif antara kecerdasan emosional $\left(\mathrm{X}_{1}\right)$ dan kemampuan menulis narasi $(\mathrm{Y})$. Perhitungan analisis regresi sederhana berdasarkan data variabel kemampuan menulis atas kecerdasan emosional menghasilkan arah regresi b sebesar 0,74 dan konstanta a sebesar 35,55. Dengan demikian bentuk hubungan antara kedua variabel tersebut dapat digambarkan melalui persamaan regresi $\hat{Y}=$ $35,55+0,74 \mathrm{X}_{1}$ (Perhitungan lengkap.

Sebelum digunakan untuk keperluan prediksi, persamaan regresi ini harus memenuhi syarat uji keberartian (signifikansi) dan uji kelinieran. Oleh karena itu untuk mengetahui derajat keberartian dan kelinieran regresi, dilakukan uji $\mathrm{F}$ dan hasilnya dapat ditelaah pada tabel berikut ini.

Tabel 1. Tabel ANAVA untuk Pengujian Signifikasi dan Linieritas Regresi $Y=35,55+0,74 X_{1}$

\begin{tabular}{|c|c|c|c|c|c|c|}
\hline \multirow{2}{*}{$\begin{array}{l}\text { Sumber } \\
\text { Varians }\end{array}$} & \multirow[t]{2}{*}{ dk } & \multirow[t]{2}{*}{ JK } & \multirow[t]{2}{*}{ RJK } & \multirow[t]{2}{*}{$\mathbf{F}_{\text {hitung }}$} & \multicolumn{2}{|c|}{$\mathbf{F}_{\text {tabel }}$} \\
\hline & & & & & $\alpha=\mathbf{0 , 0 5}$ & $\alpha=\mathbf{0 , 0 1}$ \\
\hline Total & 40 & 645866 & & & & \\
\hline Regresi (a) & 1 & 6375625 & & & & \\
\hline Regresi (b/a) & 1 & 4637,476 & 4637,476 & $48,07 * *$ & 4,10 & 7,35 \\
\hline Sisa & 38 & 3666,024 & 96,474 & & & \\
\hline Tuna cocok & 24 & 2697,468 & 112,394 & $1,079^{\text {ns }}$ & 2,35 & $\mathbf{3 , 4 3}$ \\
\hline Galat & 14 & 1457,75 & 104,125 & & & \\
\hline
\end{tabular}

Keterangan :

** : Regresi sangat signifikan $\left(\mathrm{F}_{1}=\right.$ $\left.48,07>\mathrm{F}_{1}=7,34\right)$ pada $\alpha=0,01$

ns $\quad$ : Regresi berbentuk linier $\left(\mathrm{F}_{1}=1,079\right.$ $\left.<\mathrm{F}_{1}=2,35\right)$ pada $\alpha=0,05$

$\mathrm{dk} \quad$ : Derajat kebebasan

JK : Jumlah Kuadrat

RJK : Rerata Jumlah Kuadrat

Berdasarkan hasil pengujian

signifikansi dan linearitas seperti pada tabel 4.6 di atas, dapat diketahui bahwa regresi $Y$ = $35,55+0,74 X_{1}$ sangat signifikan dan linier. Model regresi tersebut mengandung arti bahwa apabila kecerdasan emosional ditingkatkan satu poin, maka kemampuan menulis narasi cenderung meningkat 0,74 poin pada konstanta 35.55 .

Kekuatan hubungan antara variabel kecerdasan emosional $\left(\mathrm{X}_{1}\right)$ dengan kemampuan menulis narasi (Y) ditunjukkan oleh koefisien korelasi $\left(\mathrm{r}_{\mathrm{y} 1}\right)$ sebesar 0,747. Uji keberartian koefisien korelasi dengan uji t, diperoleh harga $t_{\text {hitung }}$ sebesar 6,93, sedangkan $t_{\text {tabel }}$ pada $\alpha=$ 0,01 dan $\mathrm{dk}=38$ diperoleh $\mathrm{t}_{\text {tabel }}=2,71$. Oleh karena $t_{\text {hitung }}>t_{\text {tabel }}$ maka koefisien korelasi $r_{Y 1}$ sangat signifikan. Untuk lebih jelasnya mengenai kekuatan hubungan $\mathrm{X}_{1}$ dengan $\mathrm{Y}$ dapat dilihat pada tabel berikut.

Tabel 2. Hasil Pengujian Keberartian Koefisien Korelasi $\mathrm{X}_{1}$ dengan $\mathrm{Y}$

\begin{tabular}{ccccc} 
N & $\mathbf{R}_{\mathbf{y}} \mathbf{1}$ & $\mathbf{T}_{\text {hitung }}$ & \multicolumn{2}{c}{$\mathbf{T}_{\text {tabel }}$} \\
\cline { 4 - 5 } & & & $\boldsymbol{\alpha}=\mathbf{0 , 0 5}$ & $\boldsymbol{\alpha}=\mathbf{0 , 0 1}$ \\
\hline 40 & 0,747 & $6,93^{* *}$ & 2,02 & 2,71
\end{tabular}

Keterangan:

$* *=$ Koefisien korelasi sangat signifikan $\left(\mathrm{t}_{\mathrm{h}}=\right.$ $6,93>\mathrm{t}_{1}=2,71$ ) pada $\alpha=0,01$

$r_{y 1}=$ Koefisien korelasi antara $X_{1}$ dengan $Y$ Berdasarkan hasil pengujian signifikansi sebagaimana disajikan pada tabel 4.7 ternyata koefisien korelasi antara kecerdasan emosional dengan kemampuan menulis sangat signifikan. Dengan demikian, hipotesis penelitian yang menyatakan bahwa terdapat hubungan positif antara kecerdasan emosional dan kemampuan menulis narasi teruji kebenarannya. Dalam hal ini, makin tinggi kecerdasan emosional akan semakin tinggi kemampuan menulis narasinya.

Koefisien determinasi merupakan kuadrat dari koefisien korelasi antara kecerdasan emosional dengan kemampuan menulis narasi yaitu $\left(\mathrm{r}_{\mathrm{y} 1}\right)^{2}=(0,747)^{2}=0,5580$. Artinya $55,80 \%$ variasi yang terjadi pada kemampuan menulis narasi dapat dijelaskan oleh variasi kecerdasan emosional.

Untuk mengetahui hubungan antara kecerdasan emosional dan kemampun menulis narasi, dengan melakukan pengontrolan terhadap variabel berpikir kreatif dan dilakukan perhitungan koefisien korelasi parsial. Koefisien korelasi parsial yang diperoleh antara $\mathrm{Y}$ dengan $\mathrm{X}_{1}$ apabila dilakukan pengontrolan terhadap variabel $X_{2}\left(\begin{array}{lll}r_{y} & 1.2\end{array}\right)=0,68 . \quad U j i$ keberartian koefisien korelasi parsial tersebut dilakukan dengan uji t. Hasil pengujiannya tertera pada tabel berikut. 
Tabel 3. Rangkuman Koefisien Korelasi

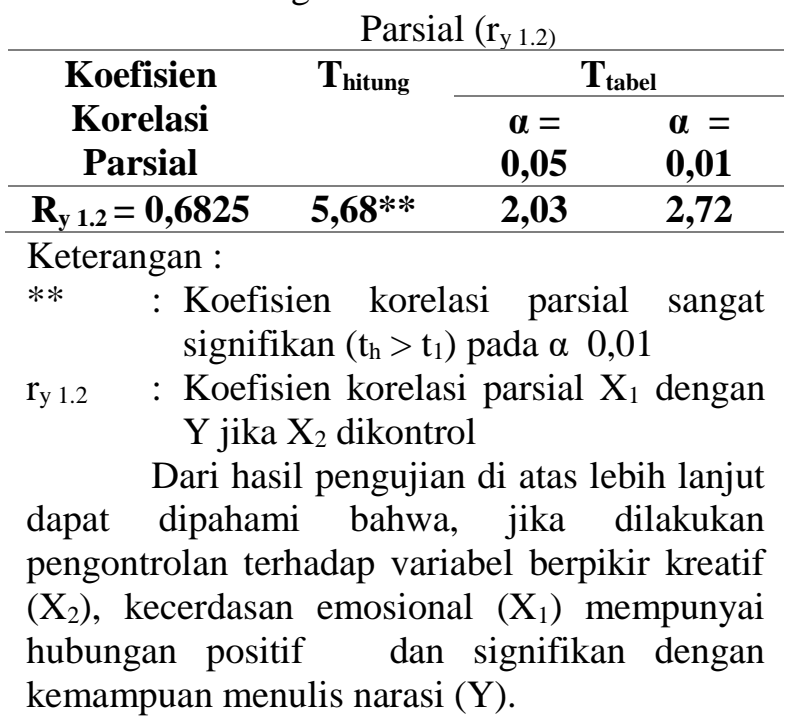

\section{Hubungan Berpikir Kreatif dengan Kemampuan Menulis Narasi}

Hipotesis kedua yang diajukan dalam penelitian ini menyatakan bahwa terdapat hubungan positif berpikir kreatif $\left(\mathrm{X}_{2}\right)$ dengan kemampuan menulis narasi (Y). Perhitungan analisis regresi sederhana berdasarkan data variabel kemampuan menulis narasi atas berpikir kreatif menghasilkan arah regresi $b$ sebesar 0,90 dan konstanta a sebesar 57,69. Dengan demikian bentuk hubungan antara kedua variabel tersebut dapat digambarkan melalui persamaan regresi $Y=57,69+0,90 \mathrm{X}_{2}$

Sebelum digunakan untuk keperluan prediksi, persamaan regresi ini harus memenuhi syarat uji keberartian (signifikansi) dan uji kelinieran. Oleh karena itu, untuk mengetahui derajat keberartian dan kelinieran regresi, dilakukan uji $\mathrm{F}$ dan hasilnya dapat ditelaah pada tabel 4 .

Tabel 4. Tabel ANAVA untuk Pengujian Keberartian dan Linieritas Regresi $\mathrm{Y}=57,69+0,90 \mathrm{X}_{2}$

\begin{tabular}{lcccccc}
\hline \multicolumn{1}{c}{$\begin{array}{c}\text { Sumber } \\
\text { Varians }\end{array}$} & dk & JK & RJK & F $_{\text {hitung }}$ & \multicolumn{2}{c}{ F $_{\text {tabel }}$} \\
\hline Total & 40 & 645866 & & & & \\
\hline Regresi (a) & 1 & 637562.5 & & & & \\
Regresi (b/a) & 1 & 4148,282 & 4148,282 & $37,94^{* *}$ & 4,10 & 7,35 \\
sisa & 38 & 4155,218 & 109,348 & & & \\
\hline Tuna cocok & $\mathbf{2 4}$ & $\mathbf{2 6 9 7 , 4 5 6 8}$ & $\mathbf{1 1 2 , 3 9 4}$ & $\mathbf{1 , 0 7 9}^{\text {ns }}$ & $\mathbf{2 , 3 5}$ & $\mathbf{3 , 4 3}$ \\
Galat & $\mathbf{1 4}$ & $\mathbf{1 4 5 7 , 7 5}$ & $\mathbf{1 0 4 , 1 2 5}$ & & & \\
\hline
\end{tabular}

Keterangan :

** : Regresi sangat signifikan $\left(\mathrm{F}_{\mathrm{h}}=\right.$ $\left.37,94>\mathrm{F}_{1}=7,35\right)$ pada $\alpha=0,01$

ns : Regresi berbentuk linier $\left(\mathrm{F}_{\mathrm{h}}=\right.$ $\left.1,079<\mathrm{F}_{1}=2,35\right)$ pada $\alpha=0,05$

dk : Derajat kebebasan

JK : Jumlah Kuadrat

RJk : Rerata jumlah kuadrat

Berdasarkan hasil pengujian signifikasi dan linieritas seperti pada tabel di atas, dapat diketahui bahwa regresi $\hat{Y}=57,69+0,90 \mathrm{X}_{2}$ sangat signifikan dan linier. Model regresi tersebut mengandung arti bahwa apabila berpikir kreatif ditingkatkan satu poin, maka kemampuan menulis narasi cenderung meningkat sebesar 0,90 poin pada konstanta 57,69 .

Kekuatan hubungan antara variabel kemampuan berpikir kreatif $\left(\mathrm{X}_{2}\right)$ dengan kemampuan menulis narasi (Y) ditujukkan oleh koefisien korelasi $\left(\mathrm{r}_{\mathrm{y} 2}\right)$ sebesar 0,707. Uji keberartian koefisien korelasi dengan uji t. diperoleh harga $t_{\text {hitung }}$ sebesar 6,16, sedangkan $\mathrm{t}_{\text {tabel }}$ pada $\alpha=0,01$ dan $\mathrm{dk}=38$ diperoleh $\mathrm{t}_{\text {tabel }}=$ 2,71 . Oleh karena $t_{\text {hitung }}>t_{\text {tabel }}$ maka koefisien korelasi $r_{y 2}$ sangat signifikan. Untuk lebih jelasnya mengenai kekuatan hubungan $\mathrm{X}_{2}$ dengan Y dapat dilihat pada tabel 5 berikut.

Tabel 5. Hasil Pengujian Koefisien Korelasi Antara $\mathrm{X}_{2}$ dengan $\mathrm{Y}$

\begin{tabular}{llll}
$n$ & $\mathbf{R}_{\mathrm{Y} 2}$ & thitung & \multicolumn{1}{c}{$\mathbf{T}_{\text {tabel }}$} \\
\cline { 3 - 4 } & & $\alpha=0,05$ & $\alpha=$ \\
& & & $\mathbf{0 , 0 1}$
\end{tabular}

$\begin{array}{llll}40 & 0,707 & 6,16 * * & 2,02\end{array}$

Keterangan

** : Koefisien korelasi sangat signifikan $\left(t_{h}\right.$ $\left.=6,18>\mathrm{t}_{\mathrm{t}}=2,71\right)$ pada $\alpha=0,01$

$r_{y 2}$ : Koefisien korelasi antara $X_{2}$ dengan $Y$ Berdasarkan hasil pengujian signifikansi seperti tabel 4.10 ternyata koefisien korelasi antara berpikir kreatif dan kemampuan 
menulis narasi sangat signifikan. Dengan demikian, hipotesis penelitian yang menyatakan terdapat hubungan positif berpikir kreatif dengan kemampuan menulis narasi teruji kebenarannya. Dalam hal ini, makin tinggi berpikir kreatif seorang akan semakin tinggi kemampuan menulis narasinya.

Koefisien determinasi merupakan kuadrat dari koefisien korelasi berpikir kreatif dengan kemampuan menulis narasi yaitu $\left(r_{y}\right)^{2}$ $=(0,707)^{2}=0,4999$. Artinya 49,99\% variasi yang terjadi pada kemampuan menulis narasi dapat dijelaskan oleh variasi berpikir kreatif.

Untuk mengetahui hubungan berpikir kreatif dengan kemampuan menulis narasi apabila dilakukan pengontrolan terhadap variabel kecerdasan emosional $\left(\mathrm{X}_{1}\right)$ dan variabel dilakukan perhitungan koefisien korelasi parsial. Berdasarkan hasil perhitungan diperoleh koefisien korelasi parsial ( $\left.\mathrm{r}_{\mathrm{y} 2.1}\right)$ sebesar 0,63. Uji keberartian koefisien korelasi parsial dengan uji $\mathrm{t}$, diperoleh harta $\mathrm{t}_{\text {hitung }}$ sebesar 3,82 dan $\mathrm{t}_{\text {tabel }}$ pada $\alpha=0,01$ dengan dk 37 diperoleh $t_{\text {tabel }}$ sebesar 2,73 (Perhitungan lengkap lihat lampiran 7.2.3). Oleh karena harga $t_{\text {hitung }}(3,82)>t_{\text {tabel }}(2,72)$ dapat disimpulkan bahwa koefisien korelasi parsial sangat signifikasi.

Tabel 6. Rangkuman Perhitungan Koefisien Korelasi Parsial $\mathrm{r}_{\mathrm{y} 2}$

\begin{tabular}{|c|c|c|c|}
\hline \multirow{2}{*}{$\begin{array}{c}\text { Koefisien } \\
\text { KorelasiParsial }\end{array}$} & \multirow[t]{2}{*}{$\mathbf{t}_{\text {hitung }}$} & \multicolumn{2}{|c|}{$\mathbf{t}_{\text {tabel }}$} \\
\hline & & $\begin{array}{l}\alpha= \\
0,05\end{array}$ & $\begin{array}{l}\alpha= \\
0,01\end{array}$ \\
\hline$R_{y 2.1}=0,6281$ & $3,82 * *$ & 2,03 & 2,72 \\
\hline
\end{tabular}

Keterangan :
** : Koefisien korelasi parsial sangat signifikan $\left(t_{h}>t_{\mathrm{t}}\right)$ pada $\alpha=0,01$

$r_{y 2.1}$ : Koefisien korelasi parsial $X_{2}$ dengan $\mathrm{Y}$ jika $\mathrm{X}_{1}$ dikontrol.

Interpretasi dari hasil pengujian di atas, adalah apabila dilakukan pengontrolan terhadap variabel kecerdasan emosional $\left(\mathrm{X}_{1}\right)$, ternyata terdapat hubungan positif dan signifikan antara variabel kemampuan berpikir kreatif dengan kemampuan menulis narasi.

\section{Hubungan Kecerdasan Emosional dan Kemampuan Berpikir Kreatif dengan Kemampuan Menulis Narasi}

Hipotesis ketiga yang diajukan dalam penelitian ini menyatakan terdapat hubungan positif antara kecerdasan emosional dan berpikir kreatif secara bersama-sama dengan kemampuan menulis narasi.

Perhitungan analisis regresi jamak berdasarkan data variabel kemampuan menulis narasi atau kecerdasan emosional menghasilkan arah regresi $a_{1}$ sebagai 0,54 untuk kecerdasan emosional $\left(X_{1}, a^{2}\right.$ sebesar 0,60 untuk berpikir kreatif $\left(\mathrm{X}_{2}\right)$, serta konstanta a sebesar 15,55. Dengan demikian bentuk hubungan antara kedua variabel bebas secara bersama-sama dengan variabel terikat tersebut dapat digambarkan melalui persamaan regresi $\hat{Y}=15,55+0,54 X_{1}+0,60 X_{2}$

Sebelum digunakan untuk keperluan prediksi, persamaan regresi ini harus memenuhi syarat uji keberartian (signifikansi) regresi. Untuk mengetahui derajat keberartian dan kelinieran regresi, dilakukan uji keberartian (signifikansi) regresi.

Tabel 7. Tabel ANAVA untuk Pengujian Signifikansi Regresi $Y=15,55+0,54 \mathrm{X}_{1}+0,60 \mathrm{X}_{2}$

\begin{tabular}{lcccccc}
\hline \multicolumn{1}{l}{$\begin{array}{l}\text { Sumber } \\
\text { Varians }\end{array}$} & Dk & Jk & RJK & F $_{\text {hitung }}$ & \multicolumn{2}{c}{ F $_{\text {tabel }}$} \\
\cline { 6 - 7 } Regresi & & & & & $\alpha=\mathbf{0 , 0 5}$ & $\alpha=\mathbf{0 , 0 1}$ \\
Sisa & $\mathbf{2}$ & $\mathbf{6 0 8 3 , 8 3 1}$ & $\mathbf{3 0 4 1 , 9 1 6}$ & $\mathbf{5 0 , 7 0 6 * *}$ & $\mathbf{3 , 2 5}$ & $\mathbf{5 , 2 3}$ \\
\hline
\end{tabular}

Keterangan :

** : Regresi sangat signifikan ( $\mathrm{F}_{\text {hitung }}$

$50,706>\mathrm{F}_{\text {tabel }} 5,23$ )

DK : Derajat Kebebasan

JK : Jumlah Kuadrat

RJK : Rerata Jumlah Kuadrat

Berdasarkan hasil pengujian signifikasi seperti pada tabel di atas, dapat diketahui bahwa regresi $Y=15,55+0,54 \mathrm{X}_{1}$ $+0,60 \mathrm{X}_{2}$ sangat signifikan.
Kekuatan koefisien korelasi jamak antara variabel $\mathrm{X}_{1}$ dan $\mathrm{X}_{2}$ dan dengan variabel $\mathrm{Y}$ menghasilkan koefisien korelasi jamak $\mathrm{R}=0,856$ (Perhitungan lengkap lihat lampiran 8.2). Uji keberartin koefisien korelasi jamak dengan uji $\mathrm{F}$, diperoleh harga $\mathrm{F}_{\text {hitung }}$ sebesar 50,71 sedangkan $\mathrm{F}_{\text {tabel }}$ pada $\alpha$ $=0,01 \mathrm{dan} \mathrm{dk}$ pembilang $=2 \mathrm{dan} \mathrm{dk}$ penyebut $=37$ diperoleh $F_{\text {tabel }}=5,23$. Oleh karena $F_{\text {hitung }}>F_{\text {abel }}$ maka koefisien korelasi jamak sangat signifikan. Untuk lebih jelasnya 
mengenai kekuatan hubungan $\mathrm{X}_{1}$ dengan $\mathrm{Y}$ dapat dilihat pada tabel 8 berikut.

Tabel 8. Uji Keberartian Koefisien Korelasi

\begin{tabular}{|c|c|c|c|c|}
\hline \multicolumn{5}{|c|}{ Jamak } \\
\hline \multirow[t]{2}{*}{$\mathbf{n}$} & \multirow{2}{*}{$\mathbf{R}_{\mathbf{y} .12}$} & \multirow[t]{2}{*}{$F_{\text {hitung }}$} & \multicolumn{2}{|c|}{$\mathbf{F}_{\text {tabel }}$} \\
\hline & & & $\alpha=\mathbf{0 , 0 5}$ & $\begin{array}{l}\alpha= \\
0,01\end{array}$ \\
\hline 40 & 0,856 & $50,71 * *$ & 3,25 & 5,23 \\
\hline \multicolumn{5}{|c|}{ Keterangan } \\
\hline$* *$ & \multicolumn{4}{|c|}{$\begin{array}{l}: \text { Koefisien korelasi jamak sangat } \\
\text { signifikan }\left(\mathrm{F}_{\mathrm{h}}=50,71>\mathrm{F}_{\mathrm{t}}=5,23\right) \\
\text { pada } \alpha=0,01\end{array}$} \\
\hline $\mathrm{R}_{\mathrm{y} .12}$ & \multicolumn{4}{|c|}{$\begin{array}{l}\text { Koefisien korelasi antara } \mathrm{X}_{1} \mathrm{X}_{2} \\
\text { secara bersama-sama dengan Y }\end{array}$} \\
\hline
\end{tabular}

Berdasarkan hasil pengujian signifikansi seperti tabel 4.12, dapat diketahui bahwa koefisien korelasi jamak dalam penelitian ini terbukti sangat signifikan. Temuan ini membuktikan bahwa terdapat hubungan positif antara kecerdasan emosional dan berpikir kreatif secara bersama-sama dengan kemampuan menulis narasi teruji kebenarannya.

Koefisien determinasi $\left(\mathrm{R}_{\mathrm{y} .12}\right)$ adalah sebesar $\left(\mathrm{R}_{\mathrm{y} .12}\right)^{2}=(0,856)^{2}=0,7327$ artinya $73,27 \%$ variasi yang terjadi pada kemampuan menulis narasi dapat dijelaskan oleh variasi

\section{PEMBAHASAN}

\section{Kecerdasan Emosional}

Dari hasil analisis statistik deskriptif diperoleh hasil skor rata-rata kecerdasan emosional $=122.15$, Median $=126$, dan Modus $=131$. Hal ini menunjukkan bahwa mahasiswa Jurusan Bahasa dan Sastra Indonesia memiliki skor rata-rata untuk kecerdasan emosional.

Hasil pengujian hipotesis kecerdasan emosional menunjukkan bahwa terdapat hubungan positif dan signifikan antara kecerdasan emosional dan kemampuan menulis narasi, ditunjukkan oleh nilai indesk determinasi $\left(\mathrm{r}_{\mathrm{y} 1}\right)^{2}=0.5580$. Hal ini berarti bahwa $55.80 \%$ kemampuan menulis narasi mahasiswa dipengaruhi oleh kecerdasan emosional.

Berdasarkan penelitian tersebut, dapatlah disimpulkan bahwa ada hubungan positif dan signifikan antara kecerdasan emosional dan kemampuan menulis narasi. Artinya, semakin tinggi kecerdasan emosional seseorang semakin tinggi pula kemampuan menulis narasinya begitu pula sebaliknya semakin rendah kecerdasan emosional kecerdasan emosional dan kemampuan berpikir kreatif. Melihat koefisien determinasi yang cukup besar yaitu 73,27\% berarti selebihnya merupakan sumbangan variabel lain. Nilai persentase sumbangan kecerdasan emosional dan berpikir kreatif secara bersama-sama terhadap kemampuan menulis narasi cukup besar.

Peringkat kekuatan hubungan antara setiap variabel bebas dengan variabel terikat dalam penelitian ini yang didasarkan atas perhitungan koefisien korelasi parsial tampak pada tabel 9 .

Tabel 9. Peringkat Kekuatan Hubungan antara Variabel Bebas dengan Variabel Terikat.

\begin{tabular}{cc}
\hline $\begin{array}{c}\text { Koefisien Korelasi } \\
\text { Parsial }\end{array}$ & Peringkat \\
\hline $\mathbf{R}_{\mathbf{y} 1.2}=\mathbf{0 , 6 8 2 5}$ & Pertama \\
\hline $\mathbf{R}_{\mathbf{y} 2.1}=\mathbf{0 , 6 2 8 1}$ & Kedua \\
\hline
\end{tabular}

Berdasarkan tabel 9 tampak bahwa variabel bebas yang paling kuat hubungan secara parsial dengan variabel terikat adalah kecerdasan emosional $\left(\mathrm{X}_{1}\right)$ sebagai peringkat pertama, diikuti oleh berpikir kreatif $\left(\mathrm{X}_{2}\right)$ sebagai peringkat kedua.

seseorang semakin rendah pula kemampuan menulis narasinya.

\section{Berpikir Kreatif}

Hasil analisis statistik deskriptif menunjukkan bahwa skor rata-rata berpikir kreatif $=75.82$, median $=78.5$, dan modus $=$ 87. Hal ini mengisyaratkan bahwa mahasiswa Jurusan Bahasa dan Sastra Indonesia Prodi Pendidikan Bahasa memiliki skor rata-rata untuk berpikir kreatif.

Dari analisis yang telah dilakukan, terlihat bahwa para mahasiswa memiliki skor yang beragam. Keberagaman skor tersebut menunjukkan bahwa berpikir kreatif di antara mereka berbeda satu sama lain. Perbedaan ini disebabkan banyak faktor. Dari pengamatan yang dilakukan dan berdasarkan pada hasil wawancara dengan mereka, secara garis besar perbedaan tersebut disebabkan oleh; Pertama. Mereka merasa mengalami kesulitan dalam mengolah kata-kata karena jarangnya mereka berimajinasi yang kemudian dituangkannya ke dalam bentuk tulisan, seperti kelancaran membuat satu kata, berpikir yang tidak biasa, dan sebagainya; kedua. Tes uji berpikir kreatif 
bagi sebagian besar dari mereka adalah pengalaman pertama. Mereka umumnya hanya tahu jenis tes untuk mengukur inteligensi. Namun, umumnya mereka merasa senang karena mereka memiliki pengalaman untuk menuangkan pikiran dan daya imajinasinya ke dalam bentuk tulisan juga mereka dapat berpikir tidak biasa. Misalnya dalam tes penggunaan yang tidak biasa.

Hasil analisis hubungan berpikir kreatif dengan kemampuan menulis narasi menunjukkan bahwa semakin tinggi skor berpikir kreatif, semakin tinggi pula kemampuan menulis narasinya. Kontribusi variabel berpikir kreatif terhadap kemampuan menulis ditandai dengan nilai $\left(\mathrm{r}_{\mathrm{y} 2}\right)^{2}=0.4999$. Hal ini berarti sebanyak $49.99 \%$ berpikir kreatif berpengaruh secara signifikan terhadap kemampuan menulis narasi.

Berdasarkan hasil analisis tersebut, dapatlah disimpulkan bahwa ada hubungan positif dan signifikan antara berpikir kreatif dengan kemampuan menulis narasi. Artinya, semakin tinggi berpikir kreatif seseorang semakin tinggi pula kemampuan menulis narasinya begitu pula sebaliknya semakin rendah berpikir kreatif seseorang semakin rendah pula kemampuan menulis narasinya

\section{Kecerdasan Emosional dan Berpikir Kreatif secara Simultan Memiliki Hubungan yang Signifikan dengan Kemampuan Menulis Narasi}

Analisis statistik korelasi ganda menghasilkan koefisien korelasi ganda $\left(\mathrm{R}_{\mathrm{y} 12}\right)$ sebesar 0.856 , dan koefisien determinasi $\left(\mathrm{R}_{\mathrm{y} 12}\right)^{2}$ sebesar 0.7327 . Hal ini berarti sebanyak 73.27 $\%$ kemampuan menulis narasi dipengaruhi oleh kecerdasan emosional dan berpikir kreatif secara bersama-sama. Kontribusi ini lebih besar daripada kontribusi setiap variabel secara individu, yaitu ; kontribusi kecerdasan emosional sebanyak $55.80 \%$ terhadap Kemampuan Menulis Narasi; dan kontribusi Berpikir Kreatif sebanyak $49.99 \%$. Hal ini menunjukkan bahwa kemampuan menulis narasi akan jauh lebih baik apabila mahasiswa memiliki kecerdasan emosional dan berpikir kreatif yang baik pula.

Dengan kontribusi variabel kecerdasan emosional dan berpikir kreatif terhadap kemampuan menulis sebagaimana dijelaskan di atas, maka dapatlah disimpulkan bahwa semakin tinggi kecerdasan emosional dan semakin kreatif seseorang dalam berpikir kreatif akan semakin tinggi pula kemampuannya dalam menulis narasi. Demikian pula sebaliknya, semakin rendah kecerdasan emosional dan semakin kurang kreatif seseorang dalam berpikir, maka semakin rendah pula kemampuannya dalam menulis narasi.

\section{PENUTUP}

Kesimpulan pokok yang dapat diungkapkan dalam penelitian ini, yaitu : (1) terdapat hubungan positif dan signifikan kecerdasan emosional dengan kemampuan menulis narasi; (2) terdapat hubungan positif dan signifikan berpikir kreatif dengan kemampuan menulis narasi; dan (3) terdapat hubungan positif dan signifikan kecerdasan emosional dan berpikir kreatif secara bersamasama dengan kemampuan menulis.

Berikut akan dijelaskan hasil penelitian ini secara rinci:

(1) Kecerdasan Emosional (X1) memiliki hubungan positif dan signifikan dengan kemampuan menulis narasi $(\mathrm{Y})$. Hal ini dibuktikan dengan nilai koefisien korelasi $\left(\mathrm{ry}_{1}\right)=0.747$, Koefisien determinasi $\left(\mathrm{ry}_{1}\right)^{2}$ $=0.5580$ yang menunjukkan bahwa 55.80 $\%$ dari kemampuan menulis dipengaruhi oleh kecerdasan emosional. Dengan demikian, kecerdasan emosional secara konsisten memiliki hubungan langsung dengan kemampuan menulis narasi. Artinya, semakin tinggi kecerdasan emosional seseorang semakin tinggi pula kemampuan menulis narasinya. Begitu pula sebaliknya, semakin rendah kecerdasan emosional seseorang semakin rendah pula kemampuan menulis narasinya.

(2) Berpikir Kreatif $\left(\mathrm{X}_{2}\right)$ memiliki hubungan positif dan signifikan dengan kemampuan menulis narasi (Y). Hal ini dapat dijelaskan dengan nilai koefisien korelasi $\left(\mathrm{ry}_{2}\right)$ sebesar 0.707 , Koefisien determinasi $\left(\mathrm{ry}_{2}\right)^{2}=0.4999$, menunjukkan bahwa 49.99 $\%$ dari kemampuan menulis narasi dipengaruhi oleh berpikir kreatif. Dengan demikian, berpikir kreatif secara konsisten memiliki hubungan langsung dengan kemampuan menulis narasi, artinya semakin tinggi berpikir kreatif seseorang semakin tinggi pula kemampuan menulis narasi orang tersebut. Begitu pula sebaliknya, semakin rendah berpikir kreatif 
seseorang semakin rendah pula kemampuan menulis narasi orang tersebut.

(3) Kecerdasan emosional $\left(\mathrm{X}_{1}\right)$ dan berpikir kreatif $\left(\mathrm{X}_{2}\right)$ secara bersama-sama memiliki hubungan positif dengan kemampuan menulis narasi (Y). Koefisien korelasi ganda $\left(\mathrm{R}_{\mathrm{v} 12}\right)$ kedua variabel tersebut diperoleh sebesar 0.856, dan koefisien determinasi $\left(\mathrm{R}_{\mathrm{y} 12}\right)^{2}=0.7327$, menunjukkan bahwa $73.277 \%$ dari kemampuan menulis narasi dipengaruhi oleh kecerdasan emosional dan berpikir kreatif. Dengan demikian, kecerdasan emosional dan berpikir kreatif secara bersama-sama konsisten memiliki hubungan langsung dengan kemampuan menulis narasi. Artinya, semakin tinggi kecerdasan emosional dan berpikir kreatif seseorang semakin tinggi pula kemampuan menulis narasinya Begitu pula sebaliknya, semakin rendah kecerdasan emosional dan berpikir kreatif seseorang secara bersama-sama, semakin rendah pula kemampuan menulis narasi orang tersebut.

\section{DAFTAR PUSTAKA}

Adler, H. (2001). Boost your Intelligence: Pacu IQ dan EQ Anda (Terj. Cristina Prianingsih) Jakarta: Erlangga

Akhmadi, M. (1990). Dasar-dasar Komposisi Bahasa Indonesia Malang: Yayasan Asih Asah Asuh

Anita, W. (1993). Education Psyhology. Needham: Allyu \& Bacon

Chomsky, N. (1995). Aspects Of The Theory Of Syntax. Cambridge: M.I.T. Press

Crimmon. M. (1984). Writing With A Purpose. USA: Houghton Miltin Company

DePorter, B. \& Hernacky. (2000). "Quantum Learning" Membiasakan Belajar Nyaman dan Menyenangkan, terj. oleh: Alawiyah Abdurrahman Bandung: Kalfa

Gie, T.L. (1995). Pengantar Dunia KarangMengarang. Yogyakarta Liberty

Gillespie, S., Linda, S., \& Singleton, R. (1982). Shaping Prose USA: Litte Brown
Goleman, D. (1999). Kecerdasan Emosi Untuk Mencapai Puncak Prestasi Jakarta: Gramedia Pustaka Utama (1995). Emotional Intelligence. United States Of America A: Bantam Book (1998). Working with Emotional Intelligence. Great Britain: Bloomsbury

Heaton, J.B. (1975). Writing English Language Tests. Englad: Longman Group Limited

Hughey, J.B. Wormuth, and Vennoy (1983). ESL Composition: Priciples and Techniques. Cambridge: Newbury Home Publisher

Keraf, G. (2001). Argumentasi dan Narasi. Jakarta: Gramedia Pustaka Utama

Mihalyi, C. (1996). Creativity. New York: Harper Collins Publisher

Munandar, S.C.U. (2003). Creativity and Education. Proyek Pengadaan Penerjemah Buku: Direktorat jenderal Pendidikan Tinggi Departemen Pendidikan dan Kebudayaan , (2002). Kreativitas dan Keberbakataan. Jakarta: Gramedia Pustaka Utama

Newman, P.R., Barbara R Newman (1983). Principles of Psyhology. Illinois The Dorsy Press

Robinson, P.C. (1998). Academic Writing. London: Modern English Publication In Association With The British Council

Stones, E. (1971) An Introduction of Educational Psychology. Great Britanian The Channer Press

Thomas, R. Murray (1990) The Encyclopedia Of Human Development and Education Theory Research, and Studies. New York: Paragon press

Vinacke. (1974) The Psyhology Of Thinking. USA: Mc Graw-hill

Wells, G. (1981) Learning Through Interaction. London: Cambridge University Press

Wood, Robert and Harry Tolley (2003) Test Your Emotional Intelligence: How to Assess and Boost your EQ, United State. Kogan Page 